\title{
Glucocorticoid receptor is involved in the breed-dependent transcriptional regulation of $3 \beta$-hydroxysteroid dehydrogenase in the liver of preweaning piglets
}

\author{
Xian Li, Yimin Jia, Runsheng Li, Zhiyuan Sun, Xi Li, Shiyan Sui and Ruqian Zhao*
}

\begin{abstract}
Background: Hepatic $3 \beta$-hydroxysteroid dehydrogenase (3 $\beta$-HSD) plays an important role in steroid inactivation and catabolism. Serum concentrations of steroid hormones differ significantly between breeds in pigs, however the molecular mechanism regulating hepatic $3 \beta-H S D$ expression in different breeds of pigs is poorly understood. In the present study, we used preweaning purebred male Large White (LW) and Erhualian (EHL) piglets as model to investigate the breed difference in the expression and regulation of $3 \beta-H S D$ gene in porcine liver.
\end{abstract}

Results: The hepatic expression of $3 \beta-H S D$ mRNA was significantly lower $(P<0.01)$ in EHL piglets compared to that in LW piglets. Significant breed differences were detected for the hepatic expression of transcription factors such as androgen receptor (AR), glucocorticoid receptor (GR), and CCAAT/enhancer binding protein $\beta$ (C/EBP $\beta$ ). The nucleoprotein contents of $A R(P<0.05), G R(P<0.01)$ and phospho-Ser ${ }^{211} G R(P<0.01)$ were significantly higher in the liver of EHL piglets. Chromatin immunoprecipitation (ChIP) assay demonstrated significantly lower binding of GR, but not AR or C/EBP $\beta$, to 3 $\beta$-HSD gene promoter in EHL piglets $(P<0.05)$. GR was not detected to interact with C/EBP $\beta$ or $A R$ in the co-immunoprecipitation analysis.

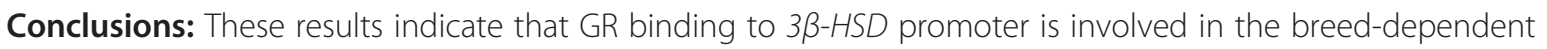
$3 \beta$-HSD expression in the liver of piglets.

Keywords: AR, C/EBP $\beta$, GR, Liver, Pig, 3ß-HSD

\section{Background}

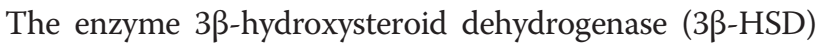
is widely distributed in various tissues of animals. In steroidogenic tissues such as adrenal gland and gonads, $3 \beta$ HSD is essential for the biosynthesis of steroid hormones $[1,2]$. In peripheral tissues such as liver and kidney, $3 \beta$ HSD catalyzes the conversion of steroids from active to inactive forms [2, 3]. Liver is the main site for steroids inactivation and catabolism [4-7]. Boar taint, an unpleasant odor of cooked pork or pork products, is partly contributed by the high level of androstenone in pig adipose tissue [8]. Boar taint can be reduced by castration, which removes the potential for androstenone production.

\footnotetext{
* Correspondence: zhao.ruqian@gmail.com

Key Laboratory of Animal Physiology and Biochemistry, Nanjing Agricultural University, Nanjing 210095, P. R. China
}

(c) 2015 Li et al.; licensee BioMed Central. This is an Open Access article distributed under the terms of the Creative Commons Attribution License (http://creativecommons.org/licenses/by/4.0), which permits unrestricted use, distribution, and reproduction in any medium, provided the original work is properly credited. The Creative Commons Public Domain Dedication waiver (http://creativecommons.org/publicdomain/zero/1.0/) applies to the data made available in this article, unless otherwise stated.

However, due to animal welfare issues and decreasing in production efficiency caused by castration, elimination of boar taint through alternative methods would be of great benefit to the pork industry. In porcine liver, $3 \beta-\mathrm{HSD}$ is responsible for the initial step of androstenone metabolism [9-12]. Pigs with low hepatic $3 \beta-H S D$ expression and activity showed a reduced rate of hepatic androstenone clearance and the accumulation of androstenone in adipose tissue $[9,13-15]$.

The expression of $3 \beta-H S D$ is predominantly regulated at the level of transcription $[2,16]$. A wide array of transcription factors have been identified to participate in the transcriptional regulation of $3 \beta-H S D$ gene $[17-20]$. For instance, CCAAT/enhancer binding protein $\beta(\mathrm{C} /$ EBP $\beta$ ), a member of CCAAT/enhancer binding protein family, has been reported to participate in the breed- 
specific expression of adrenal $3 \beta-H S D$ in pigs [21]. Steroid hormones are involved in the modulation of $3 \beta-H S D$ expression $[2,16]$. Androgens have been reported to inhibit $3 \beta-H S D$ expression in Leydig cells $[22,23]$ and adrenal fasciculata cells [24], whereas glucocorticoids stimulate $3 \beta-H S D$ expression in human adrenocortical NCI-H295R cells [25] but inhibit 3 $\beta$-HSD expression and activity in rat Leydig cells [26]. To date, majority of the studies has been focusing on the $3 \beta-H S D$ gene regulation in steroidogenic tissues, little is known about the transcriptional regulation of $3 \beta-H S D$ gene in the liver.

Chinese native pig breeds have been reported to have significantly higher plasma cortisol and testosterone concentrations compared to the Western pig breeds [21, 27-29]. Moreover, Chinese Erhualian (EHL) pigs were found to express higher glucocorticoid receptor $(G R)$ mRNA in the liver compared to Pietrain pigs [30]. In our previous study, we found that GR and androgen receptor (AR) participated in the regulation of $3 \beta-\mathrm{HSD}$ expression via proteinprotein interaction with $\mathrm{C} / \mathrm{EBP} \beta$ in procine adrenal glands [21]. However, it remains unknown whether breed differences in plasma cortisol and testosterone concentrations are associated with breed disparities in hepatic $3 \beta-H S D$ expression, and whether GR and AR are involved in the breed-dependent transcriptional regulation of $3 \beta-H S D$ in porcine liver.

Therefore, in the present study, purebred EHL and Large White (LW) preweaning male piglets with different concentrations of serum cortisol and testosterone were employed as model to investigate the breed differences in hepatic 3 3 -HSD expression and to explore the possible mechanisms underlying the breed-dependent transcriptional regulation of $3 \beta-H S D$ gene in the liver, including the role of transcription factors $\mathrm{AR}, \mathrm{GR}$ and $\mathrm{C} / \mathrm{EBP} \beta$.

\section{Methods \\ Animals}

Five preweaning purebred male LW (body weight, $8.10 \pm$ $0.34 \mathrm{~kg}$ ) and $6 \mathrm{EHL}$ (body weight, $4.08 \pm 0.25 \mathrm{~kg}$ ) piglets at the age of 25 days (d) were respectively obtained from two neighboring pig breeding farms in Changzhou, Jiangsu Province, China. As large animals, 5 to 6 pigs are enough for the lab experiments. The piglets were exsanguinated after electric stunning by a licensed slaughterhouse staff on the respective farm. Liver samples from the same regions were frozen in liquid nitrogen immediately after collection and then stored at $-70{ }^{\circ} \mathrm{C}$ for further analysis. The Animal Ethics Committee at Nanjing Agricultural University reviewed the protocol and approved this study specifically, with the project number 2009ZX08009-138B. The slaughter and sampling procedures complied with the "Guidelines on Ethical Treatment of Experimental Animals" (2006) No. 398 set by the Ministry of Science and Technology, China and "the Regulation regarding the Management and
Treatment of Experimental Animals" (2008) No.45 set by the Jiangsu Provincial People's Government.

\section{RNA isolation, CDNA synthesis and real-time PCR}

Total RNA was isolated from liver samples using Trizol Reagent (Invitrogen, USA) and then purified with DNase I (RNase Free, D2215, Takara, Japan) according to the manufacturer's instructions. Concentration of the extracted RNA was measured using NanoDrop 1000 Spectrophotometer. Denaturing agarose electrophoresis was used to confirm RNA integrity. Real-time PCR was carried out to examine DNA contamination. M-MLV reverse transcriptase (Promega, Madison, WI, USA) were used to synthesize cDNA with $2 \mu \mathrm{g}$ of total RNA following the manufacturer's instructions. Two microlitres of diluted cDNA (1:50) were used for real-time PCR using SYBR Green Real-time PCR Master Mix (TaKaRa, Japan) in Mx3000P (Stratagene, USA). All primers (Table 1) were synthesized by Generay Biotech Co., Ltd. (Shanghai, China). Several reference genes (18S, GAPDH, ACTB and PPIA) were tested for mRNA quantification. The expression stability was evaluated by geNorm [31] and peptidylprolyl isomerase A (PPIA) was shown to be the most stable and did not show difference in expression between indigenous Chinese pig breeds and western breeds [32]. Therefore PPIA was chosen as the reference gene. The method of $2^{-\Delta \Delta C t}$ was used to analyze the real-time PCR data [33], and the mRNA levels were expressed as the fold change relative to the mean value of LW pigs.

\section{Protein extraction and Western blot analysis}

Nuclearprotein extracts from $100 \mathrm{mg}$ frozen liver tissue were prepared as previously described with some modifications [34]. Briefly, approximately $100 \mathrm{mg}$ frozen liver samples were homogenized in $1 \mathrm{~mL}$ of low-salt buffer (20 mM HEPES pH 8.0, $10 \mathrm{mM} \mathrm{KCl,} 1$ mM EDTA, 1 mM EGTA, $0.2 \%$ NP-40, $10 \%$ glycerol) containing protease inhibitors cocktail (05892791001, Roche, Germany) and phosphatase inhibitors cocktail (4906837001, Roche, Germany), and incubated for $10 \mathrm{~min}$ on ice. After centrifugation for $1 \mathrm{~min}$ at $13,000 \mathrm{~g}$ at $4{ }^{\circ} \mathrm{C}$, the remaining pellet was dissolved in $100 \mu \mathrm{L}$ high-salt buffer $(420 \mathrm{mM}$ $\mathrm{NaCl}, 20 \mathrm{mM}$ HEPES pH 8.0, $10 \mathrm{mM} \mathrm{KCl}, 1 \mathrm{mM}$ EDTA, 1 mM EGTA, 20 \% glycerol, protease inhibitor cocktail, phosphatase inhibitors cocktail), kept on ice for $30 \mathrm{~min}$, and then centrifuged for $10 \mathrm{~min}$ at $13,000 \mathrm{~g}$ at $4{ }^{\circ} \mathrm{C}$. Supernatants were taken as nuclear fractions. Protein concentration was measured with the BCA Protein Assay Kit (Pierce, Rockford, IL, USA) according to the manufacturer's instructions. After denaturation, $40 \mu \mathrm{g}$ of protein, which was calibrated as the optimum loading quantity, was electrophoresed in a $7.5 \%$ or $10 \%$ SDS-PAGE gel together with a protein size ladder (SM0671, Fermentas), and the separated proteins were transferred onto the 
Table 1 Primers used in the present study

\begin{tabular}{|c|c|c|}
\hline Name & Sequence & Application \\
\hline \multirow[t]{2}{*}{ 3ß-HSD (NM_001004049.1) } & F: TTCCTGGCAAGTATTTCTCGG & \multirow[t]{10}{*}{ mRNA expression } \\
\hline & R: TCCAGCAACAAGTGGACGAT & \\
\hline \multirow[t]{2}{*}{ GR (AY779185) } & F: CCAAACTCTGCCTTGTGTGTTC & \\
\hline & R: TGTGCTGTCCTTCCACTGCT & \\
\hline \multirow[t]{2}{*}{ C/EBPß (NM_001199889.1) } & F: GACAAGCACAGCGACGAGTA & \\
\hline & R: AGCTGCTCCACCTTCTTCTG & \\
\hline \multirow[t]{2}{*}{ AR (NM_214314.2) } & F: AGCACCATACGGCTACAC & \\
\hline & R: GCCCATCTCGCTTTTGAC & \\
\hline \multirow[t]{2}{*}{ PPIA (NM_214353.1) } & F: GACTGAGTGGTTGGATGG & \\
\hline & R: TGATCTTCTTGCTGGTCTT & \\
\hline \multirow[t]{2}{*}{ C/EBPß-Site1 (-2078/-1953) } & F: ACTGCGGAGGGGCTATTG & \multirow[t]{12}{*}{ ChIP for $3 \beta$-HSD promoter AR, GR and C/EBP $\beta$ binding } \\
\hline & R: CTCAGAACTCATGCGACCAG & \\
\hline \multirow[t]{2}{*}{ C/EBPß-Site2/3 GR (-723/-576) } & F: TGAGACTITGGCCGCAATC & \\
\hline & R: GTGACTTGTGGCCTTATGCA & \\
\hline \multirow[t]{2}{*}{ C/EBPß-Site4 GR (-45/+171) AR $(-45 /+171)$} & F: GCTGAGTCAGAGGCAAGGG & \\
\hline & R: GAGGTCAGGTGATTCAGTGGAA & \\
\hline \multirow[t]{2}{*}{ GR (-371/-178) } & F: TAATCCACTGGGCGAGAC & \\
\hline & R: AACCACAGCAGGAGAAAGAT & \\
\hline \multirow[t]{2}{*}{ AR $(-298 /-79)$} & F: CCATGACAGGGACTCCTCC & \\
\hline & R: AGCTCACGCCTCCTTACTTC & \\
\hline \multirow[t]{2}{*}{ AR $(-5279 /-4985)$} & F: CCTCAAGGATAGAAGGATGG & \\
\hline & R: CAATGGGGAAAAGCGTAG & \\
\hline
\end{tabular}

nitrocellulose membranes (BioTrace, Pall Co., USA). Western blot analysis for GR (sc-1004×, Santa Cruz, USA, diluted 1:2000), phospho-Ser ${ }^{211}$ GR (ab55189, Abcam, USA, diluted 1:1000), AR (sc-815×, Santa Cruz, USA, diluted 1:2000) and C/EBP $\beta$ (sc-150×, Santa Cruz, USA, diluted 1:2000) was carried out according to the recommended protocols provided by the manufacturers. Histone H1 (BS1655, bioworld, USA, diluted 1:500) was used as a reference. Finally, the blots were detected by enhanced chemiluminescence (ECL) using the LumiGlo substrate (Super Signal West Pico Trial Kit, Pierce, USA). The ECL signals were recorded by the VERSADOC MP 4000 system (Bio-Rad, USA) and analyzed with Quantity One software (Bio-Rad, USA).

The GR, phospho-Ser ${ }^{211} \mathrm{GR}, \mathrm{AR}, \mathrm{C} / \mathrm{EBP} \beta$ and Histone $\mathrm{H} 1$ antibodies worked well in the detection of porcine proteins in high specificity, and the main band appeared at the expected molecular weight. So we cut the gel for these antibodies to include all 11 samples in one blot. The Western blot results were repeated twice.

\section{Transcription factors' prediction and Chromatin} immunoprecipitation (ChIP)

The glucocorticoid responsive element (GRE), androgen responsive element (ARE) and $\mathrm{C} / \mathrm{EBP} \beta$ binding sites were predicted on pig 3 $\beta$-HSD gene promoter, by using TF Search (http://www.cbrc.jp/research/db/TFSEARCH.html) and gene-regulation (http://www.gene-regulation.com/pub/ programs.html) online resources.

ChIP analysis was performed according to our previous publication [21, 35]. In brief, $100 \mathrm{mg}$ frozen liver samples were ground in liquid nitrogen and resuspended in PBS. After cross-linking in $1 \%$ formaldehyde, the reaction was stopped using $2.5 \mathrm{M}$ glycine. The pellets were washed using PBS and lysed with SDS lysis buffer containing protease inhibitors cocktail. The chromatin was sonicated on ice to yield DNA fragments of 200 to 500 bp in length. Then the protein-DNA complex was diluted in ChIP dilution buffer containing protease inhibitors. After pre-clearance of the chromatin preparations with salmon sperm DNA/ protein A/G plus beads (40 $\mu \mathrm{L}, 50 \%$ slurry, sc-2003, Santa Cruz, CA, USA), the immunoprecipitation was performed with $4 \mu \mathrm{g}$ GR (sc1004x, Santa Cruz, USA), AR (sc-815×, Santa Cruz, USA), C/EBP $\beta$ (sc-150×, Santa Cruz, USA) and normal rabbit IgG (sc-2027, Santa Cruz, USA) (negative control) overnight at $4{ }^{\circ} \mathrm{C}$, respectively. Protein $\mathrm{A} / \mathrm{G}$ plus beads ( $40 \mu \mathrm{L}, 50 \%$ slurry) were added to capture the immunoprecipitated chromatin complexes for $2 \mathrm{~h}$ at $4{ }^{\circ} \mathrm{C}$. Finally, reverse cross-linking was performed to release 


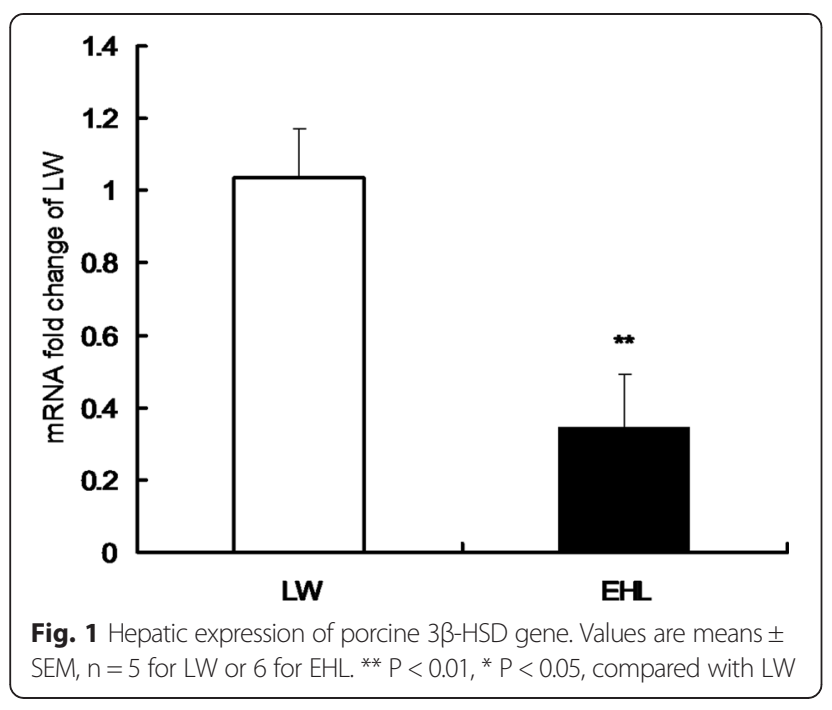

DNA fragments from the immunoprecipitated complex at $65{ }^{\circ} \mathrm{C}$ for overnight and DNA was purified. Immunoprecipitated DNA was used as template for real-time PCR and specific primers were designed to amplify genomic sequences at the promoter region of $3 \beta$-HSD gene (Table 1). ChIP results were normalized to the rabbit normal IgG precipitation and shown as fold enrichment.

\section{Co-immunoprecipitation}

Co-immunoprecipitation was performed as previously described with minor modifications [36]. Five hundred micrograms of total protein were precleared with $40 \mu \mathrm{L}$ of protein $\mathrm{A} / \mathrm{G}$ plus beads for $1 \mathrm{~h}$ at $4{ }^{\circ} \mathrm{C}$, then centrifuged at $1,000 \times \mathrm{g}$ for $5 \mathrm{~min}$. The supernatants were incubated with $4 \mu \mathrm{g} \mathrm{C} / \mathrm{EBP} \beta$ and GR antibodies and rotated overnight at $4{ }^{\circ} \mathrm{C}$. Thereafter, $40 \mu \mathrm{L}$ of agarose beeds were incubated with the protein-antibody complexes for $2 \mathrm{~h}$ at $4{ }^{\circ} \mathrm{C}$. After centrifugation, the agarose beeds were washed and the immunoprecipitated proteins were run on $7.5 \%$ SDSpolyacrylamide gel for western blot analysis.

\section{Statistical analysis}

All data were presented as mean $\pm \mathrm{SEM}$, and were analyzed using independent-samples $t$-test with SPSS 21.0 for Windows. The mRNA or protein expression was expressed as the fold change relative to LW. Difference was considered significant when $P<0.05$.

\section{Results}

Hepatic expression of $3 \beta$-HSD gene

EHL piglets showed significantly lower hepatic $3 \beta-H S D$ mRNA expression as compared to LW piglets $(P<0.01)$ (Fig. 1).
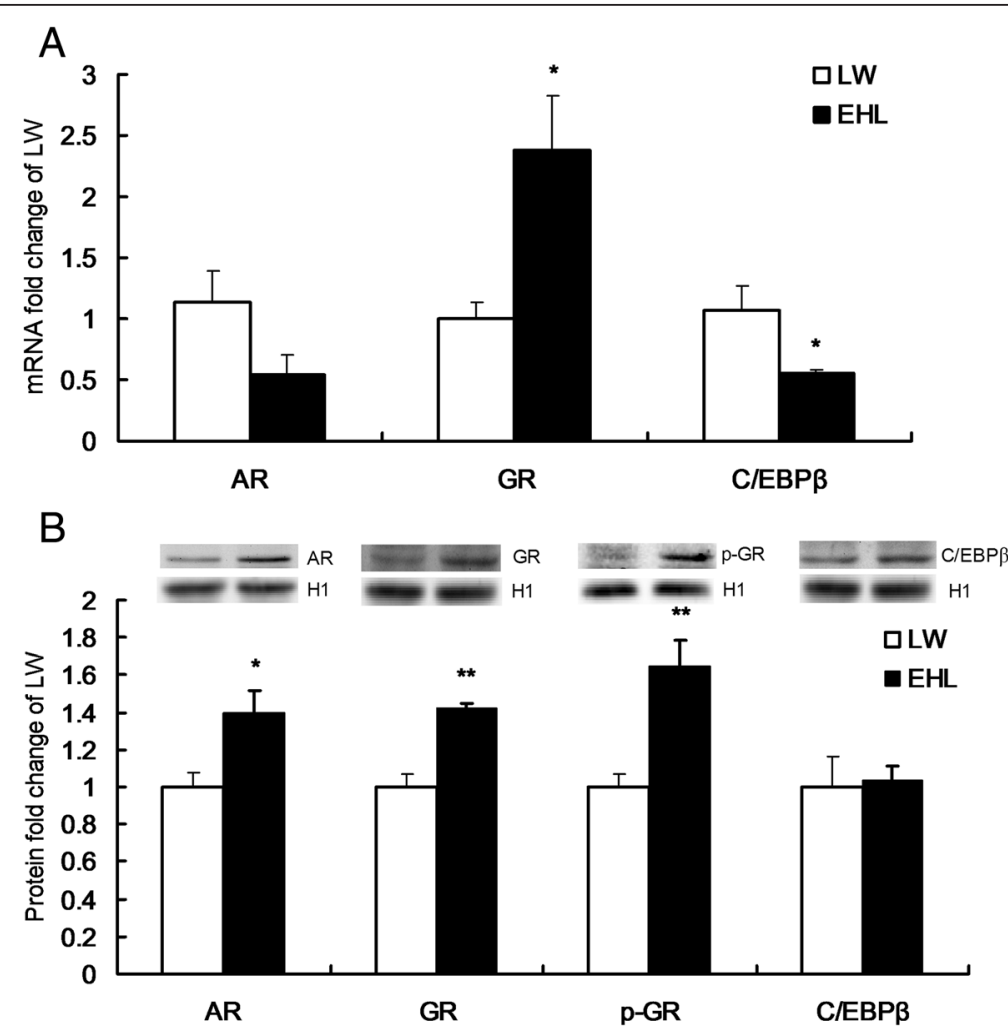

Fig. 2 Relative Hepatic expression of transcription factors. (a) Hepatic expression of genes involved in 3 $\beta$-HSD transcription. (b) Nucleoprotein content of AR, GR, phospho-Ser211GR and C/EBP $\beta$ in the liver. Values are means \pm SEM, $n=5$ for LW or 6 for EHL. * P<0.05, compared with LW 
Hepatic expression of GR, AR and C/EBP $\beta$

The mRNA expression of $A R$ tended to be lower in the liver of EHL piglets compared to that in LW $(P=0.07)$ (Fig. 2a). However, the hepatic nucleoprotein content of AR was significantly higher in EHL piglets $(P<0.05)$ (Fig. 2b). Similarly, the hepatic mRNA expression and nucleoprotein contents of GR $(P<0.01)$ and phosphoSer ${ }^{211}$ GR $(P<0.01)$ were significantly higher in EHL piglets (Fig. 2a and b). $C / E B P \beta$ mRNA expression was significantly lower in the liver of EHL piglets $(P<0.05)$, but no breed difference was observed for the protein content (Fig. 2a and b).

A

$\triangle$ putative ARE $\quad$ putative GRE $\quad$ putative C/EBPb binding site
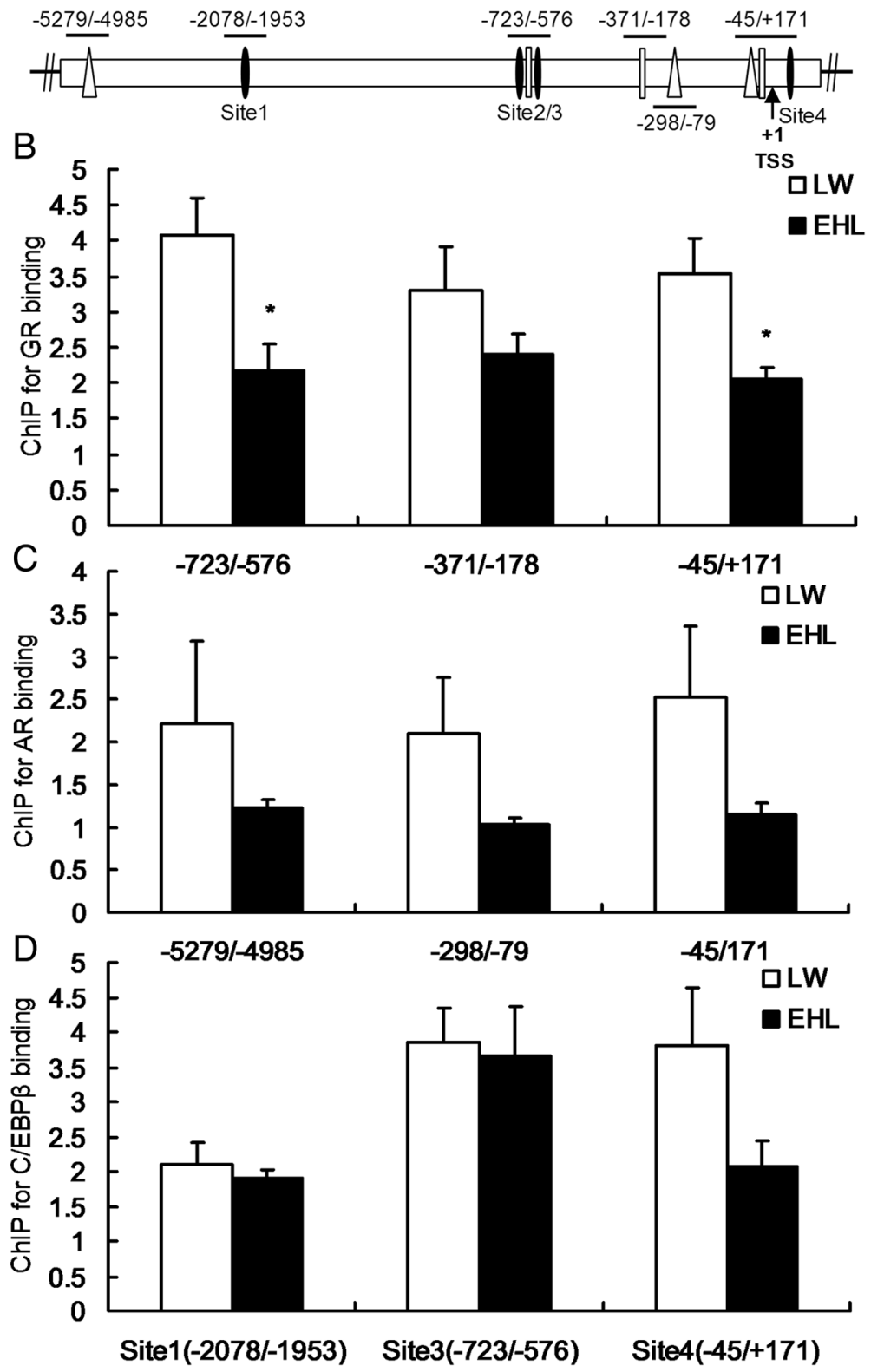

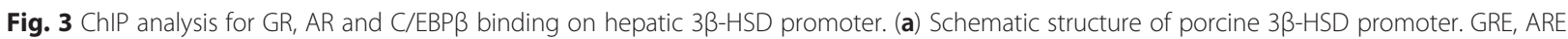
and C/EBP $\beta$ binding sites and the PCR fragments used to detect GR, AR and C/EBP $\beta$ binding are indicated; TSS: transcription start site. (b) GR

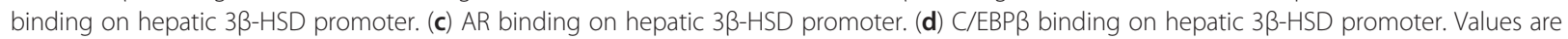
means \pm SEM, $n=5$ for LW or 6 for EHL. * $P<0.05$, compared with LW 


\section{Binding of GR, AR and C/EBP $\beta$ to $3 \beta-H S D$ promoter} Three putative GREs, 3 AREs and 4 C/EBP $\beta$ binding sites were predicted on pig $3 \beta$-HSD gene promoter (Fig. 3a). ChIP assay revealed significantly lower binding of GR to the first and the third predicted GREs on $3 \beta$ HSD promoter in the liver of EHL piglets $(P<0.05$, Fig. 3b). No significant breed difference was observed for the binding of $\mathrm{AR}$ or $\mathrm{C} / \mathrm{EBP} \beta$ to $3 \beta$-HSD promoter in the liver of preweaning piglets (Fig. $3 \mathrm{c}$ and $\mathrm{d}$ ).

\section{Interaction between $\mathrm{GR}$ and $\mathrm{C} / \mathrm{EBP} \beta$ or $\mathrm{AR}$}

Co-immunoprecipitation analysis revealed that neither AR nor $C / E B P \beta$ was detected to interact with $G R$ in the liver of EHL and LW piglets (Fig. 4).

\section{Discussion}

In this study, we provide the first evidence on the breeddependent regulation of hepatic $3 \beta-H S D$ gene transcription in the pig. EHL piglets expressed significantly lower $3 \beta-H S D$ mRNA in the liver as compared with LW piglets. This is in line with a previous report that the expression of $3 \beta-H S D$ mRNA was about 12 times higher in the liver of crossbred LW pigs compared to that in crossbred Meishan pigs [9]. However, the result is contrary to our previous study in adrenal gland, in which EHL piglets expressed significantly higher $3 \beta$ $H S D$ mRNA compared to LW piglets [21]. It suggests that different regulatory mechanisms exist in liver and adrenal gland about $3 \beta-H S D$ expression.

Steroid hormones such as cortisol and testosterone may affect the transcriptional regulation of $3 \beta-H S D$ through their respective nuclear receptors. Previously, we found that GR and AR participated in the regulation of $3 \beta-H S D$ expression via protein-protein interaction with $\mathrm{C} / \mathrm{EBP} \beta$ in procine adrenal glands [21]. In the present study, GR mRNA abundance and the nuclear content of phospho-Ser ${ }^{211} \mathrm{GR}$ were significantly higher

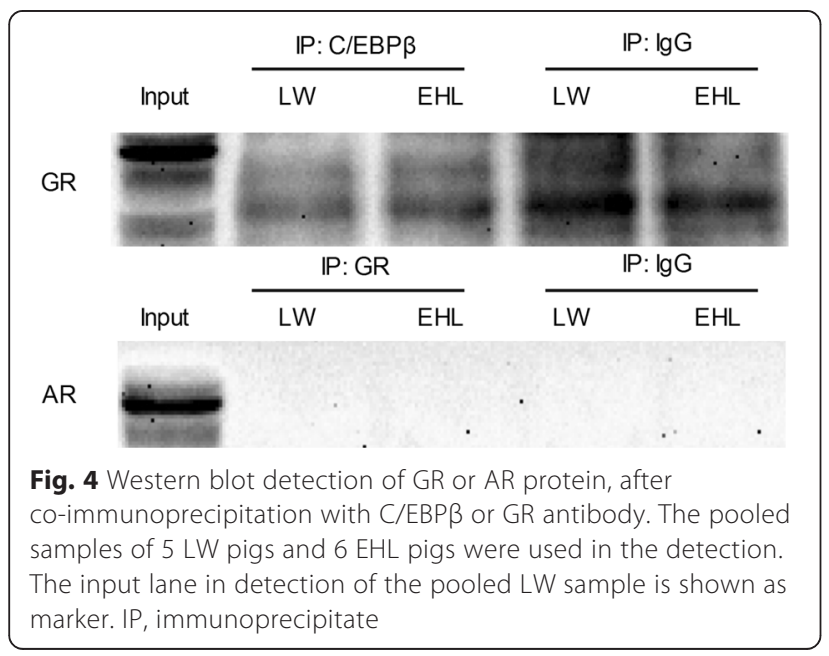

in the liver of EHL piglets as compared to that in LW piglets. This is in agreement with our previous finding that EHL pigs express higher abundance of GR mRNA in the liver as compared to Pietrain pigs [30]. The relationship between glucocorticoid concentration and GR expression is complex and appears to be species-specific. For instance, a synthetic glucocorticoid dexamethasone was reported to inhibit hepatic GR mRNA and protein levels in rats [37] and mice [38], while in Italian chickens, the hepatic GR expression was negatively correlated with the blood corticosterone level [39]. In contrast to GR, AR mRNA and protein expression seems to be uncoupled. EHL piglets were detected lower $A R$ mRNA $(P=0.07)$ yet higher AR protein in the liver as compared with LW piglets. In the process of gene transcription, protein or even phosphorylated protein levels play the pivotal regulatory roles [40]. The inconsistence between mRNA and protein suggests a post-transcriptional regulation. A similar phenomenon was described previously that testosterone decreases $A R$ mRNA but increases AR protein in human prostate adenocarcinoma (LNCaP) cells [41].

We reported previously that $C / E B P \beta$ is involved in the breed-specific expression of $3 \beta-\mathrm{HSD}$ in porcine adrenal glands [21]. In this study, $C / E B P \beta$ mRNA expression was down-regulated in the liver of EHL piglets, but no breed difference was detected for the C/EBP $\beta$ protein content. It happens that the mRNA abundance of a gene and its protein content do not match, indicating posttranscriptional or translational regulation. We did not examine the level of phosphorylated C/EBP $\beta$. So it is unknown whether breed differences can be detected for phosphorylated of $C / E B P \beta$. It is reported that $C / E B P \beta$ [42-44] and AR [45] can regulate the transcription of target genes via protein-protein interactions with GR. Using online transcription factors prediction databases, we located several putative GREs, AREs and C/EBP $\beta$ binding sites on the proximal promoter sequence of porcine $3 \beta-H S D$ gene. ChIP analysis revealed significant breed difference in the GR binding to the two predicted GREs on $3 \beta-H S D$ promoter, with lower binding detected in the liver of EHL piglets. This finding implicates the direct involvement of GR in the transcriptional regulation of porcine $3 \beta-H S D$ gene in the liver. ChIP assay is used for detecting the binding of a transcription factor with its response elements on gene promoters or regulatory sequences in tissue or cell lysates under real biological situation. Compared with electrophoretic mobility shift assay which uses labelled synthetic oligonucleotide probe to bind a transcription factor in nuclear extracts in vitro, ChIP assay reflects the binding status under real tissue or cell conditions. Certainly, binding itself is not linked directly to the function of transcritional activation or repression. A functional promoter activity analysis is required to 
evaluate the function. However, promoter activity analysis using a dual-luciferase reporter system has been also performed under an artificial scenario using transfected cell models in vitro. We did not have a porcine hepatocyte cell line and failed to transfect the primary porcine hepatocytes for functional promoter activity analysis. It is surprising that higher GR nuclear translocation in the liver of EHL piglets coincided with lower GR binding to the $3 \beta$ $H S D$ gene promoter. Nevertheless, the uncoupling of nuclear protein content and GR binding to a target gene promoter is not an unique observation. It was reported that Mycoplasma hyopneumoniae infection promotes GRmediated toll-like receptor 2 activation by increasing GR binding, without affecting GR nuclear translocation in porcine lung [46]. To elucidate whether AR and C/EBP $\beta$ also contribute to the breed difference in hepatic $3 \beta-H S D$ gene transcription in porcine liver, we also detected binding of these two transcriptional factors to $3 \beta-H S D$ gene promoter and their interactions with GR. It appears that $\mathrm{AR}$ and $\mathrm{C} / \mathrm{EBP} \beta$ are unlikely to contribute to the breed disparity in hepatic $3 \beta-H S D$ expression in EHL and LW piglets through either direct binding to the promoter, or indirect protein-protein interaction with GR.

\section{Conclusions}

Taken together, we show that the hepatic expression of $3 \beta-H S D$ gene is regulated differently between LW and EHL piglets, at the level of transcription. The GR binding to $3 \beta$-HSD promoter is responsible, at least in part, for the breed-dependent $3 \beta-H S D$ expression in liver of piglets.

\section{Abbreviations \\ 33-HSD: $3 \beta$-hydroxysteroid dehydrogenase; AR: Androgen receptor; ARE: Androgen responsive element; C/EBP $\beta$ : CCAAT/enhancer binding protein $\beta$; ChIP: Chromatin immunoprecipitation; EHL: Erhualian; GR: Glucocorticoid receptor; GRE: Glucocorticoid responsive element; LNCaP: Human prostate adenocarcinoma; LW: Large white; PPIA: Peptidylprolyl isomerase A.}

\section{Competing interests}

The authors declare that they have no competing interests.

\section{Authors' contributions}

Xian $L$ performed the experiment and drafted the manuscript. YJ, RL, ZS, Xi L and SS performed the experiment and analyzed the data. RZ conceived the idea, designed the experiment and finalized the munuscript. All authors read and approved the final manuscript.

\section{Acknowledgments \\ This work was supported by the National Basic Research Program of China (2012CB124703), the Fundamental Research Funds for the Central Universities (KYZ200913), the Major National Science and Technology Program (2009ZX08009-138B), the Special Fund for Agro-scientific Research in the Public Interest (201003011), and the Priority Academic Program Development of Jiangsu Higher Education Institutions.}

Received: 18 December 2014 Accepted: 18 May 2015 Published online: 26 May 2015

\section{References}

1. Payne AH, Hales DB. Overview of steroidogenic enzymes in the pathway from cholesterol to active steroid hormones. Endocr Rev. 2004;25(6):947-70.
2. Simard J, Ricketts ML, Gingras S, Soucy P, Feltus FA, Melner MH. Molecular biology of the 3beta-hydroxysteroid dehydrogenase/delta5-delta4 isomerase gene family. Endocr Rev. 2005;26(4):525-82.

3. Clarke TR, Bain PA, Greco TL, Payne AH. A novel mouse kidney 3 beta-hydroxysteroid dehydrogenase complementary DNA encodes a 3-ketosteroid reductase instead of a 3 beta-hydroxysteroid dehydrogenase/ delta 5-delta 4-isomerase. Mol Endocrinol. 1993;7(12):1569-78.

4. Pirog EC, Collins DC. Metabolism of dihydrotestosterone in human liver: importance of 3alpha- and 3beta-hydroxysteroid dehydrogenase. J Clin Endocrinol Metab. 1999;84(9):3217-21.

5. de Launoit Y, Zhao HF, Belanger A, Labrie F, Simard J. Expression of liver-specific member of the 3 beta-hydroxysteroid dehydrogenase family, an isoform possessing an almost exclusive 3-ketosteroid reductase activity. J Biol Chem. 1992;267(7):4513-7.

6. Rogerson FM, LeHoux JG, Mason JI. Expression and characterization of isoforms of 3 beta-hydroxysteroid dehydrogenase/delta 5-> 4-isomerase in the hamster. J Steroid Biochem Mol Biol. 1995;55(5-6):481-7.

7. Abbaszade IG, Clarke TR, Park CH, Payne AH. The mouse 3 betahydroxysteroid dehydrogenase multigene family includes two functionally distinct groups of proteins. Mol Endocrinol. 1995;9(9):1214-22.

8. Bonneau M. Compounds responsible for boar taint, with special emphasis on androstenone: a review. Livest Prod Sci. 1982;9(6):687.

9. Doran E, Whittington FM, Wood JD, McGivan JD. Characterisation of androstenone metabolism in pig liver microsomes. Chem Biol Interact. 2004;147(2):141-9.

10. Nicolau-Solano SI, McGivan JD, Whittington FM, Nieuwhof GJ, Wood JD, Doran O. Relationship between the expression of hepatic but not testicular 3beta-hydroxysteroid dehydrogenase with androstenone deposition in pig adipose tissue. J Anim Sci. 2006;84(10):2809-17.

11. Rasmussen MK, Ekstrand B. Regulation of 3beta-hydroxysteroid dehydrogenase and sulphotransferase $2 \mathrm{~A} 1$ gene expression in primary porcine hepatocytes by selected sex-steroids and plant secondary metabolites from chicory (Cichorium intybus L.) and wormwood (Artemisia sp.). Gene. 2014;536(1):53-8.

12. Moe M, Grindflek E, Doran O. Expression of 3beta-hydroxysteroid dehydrogenase, cytochrome $\mathrm{p} \mathrm{450-c17}$, and sulfotransferase 2B1 proteins in liver and testis of pigs of two breeds: relationship with adipose tissue androstenone concentration. J Anim Sci. 2007;85(11):2924-31.

13. Cue RA, Nicolau-Solano SI, McGivan JD, Wood JD, Doran O. Breedassociated variations in the sequence of the pig 3beta-hydroxysteroid dehydrogenase gene. J Anim Sci. 2007:85(3):571-6.

14. Rasmussen MK, Brunius C, Ekstrand B, Zamaratskaia G. Expression of hepatic 3beta-hydroxysteroid dehydrogenase and sulfotransferase $2 \mathrm{~A} 1$ in entire and castrated male pigs. Mol Biol Rep. 2012;39(8):7927-32.

15. Rasmussen MK, Brunius C, Zamaratskaia G, Ekstrand B. Feeding dried chicory root to pigs decrease androstenone accumulation in fat by increasing hepatic 3beta hydroxysteroid dehydrogenase expression. J Steroid Biochem Mol Biol. 2012:130(1-2):90-5.

16. King SR, Lavoie HA. Gonadal transactivation of STARD1, CYP11A1 and HSD3B. Front Biosci. 2012;17:824-46

17. Leers-Sucheta S, Morohashi K, Mason Jl, Melner MH. Synergistic activation of the human type II 3beta-hydroxysteroid dehydrogenase/delta5-delta4 isomerase promoter by the transcription factor steroidogenic factor-1/adrenal 4-binding protein and phorbol ester. J Biol Chem. 1997;272(12):7960-7.

18. Feltus FA, Groner B, Melner MH. Stat5-mediated regulation of the human type II 3beta-hydroxysteroid dehydrogenase/delta5-delta4 isomerase gene: activation by prolactin. Mol Endocrinol. 1999;13(7):1084-93.

19. Lalli E, Bardoni B, Zazopoulos E, Wurtz JM, Strom TM, Moras D, et al. A transcriptional silencing domain in DAX-1 whose mutation causes adrenal hypoplasia congenita. Mol Endocrinol. 1997;1 1(13):1950-60.

20. Martin LJ, Taniguchi H, Robert NM, Simard J, Tremblay JJ, Viger RS. GATA factors and the nuclear receptors, steroidogenic factor $1 /$ /iver receptor homolog 1, are key mutual partners in the regulation of the human 3beta-hydroxysteroid dehydrogenase type 2 promoter. Mol Endocrinol 2005;19(9):2358-70.

21. Li X, Li R, Jia Y, Sun Z, Yang X, Sun Q, et al. CCAAT/enhancer-binding protein beta is involved in the breed-dependent transcriptional regulation of 3beta-hydroxysteroid dehydrogenase/Delta-Delta-isomerase in adrenal gland of preweaning piglets. J Steroid Biochem Mol Biol. 2013;138C:273-80.

22. Stalvey JR, Clavey SM. Evidence that testosterone regulates Leydig cell 3 beta-hydroxysteroid dehydrogenase-isomerase activity by a trans-acting factor distal to the androgen receptor. J Androl. 1992;13(1):93-9. 
23. Heggland SJ, Signs SA, Stalvey JR. Testosterone decreases 3betahydroxysteroid dehydrogenase-isomerase messenger ribonucleic acid in cultured mouse Leydig cells by a strain-specific mechanism. J Androl. 1997;18(6):646-55.

24. Perry JE, Stalvey JR. Gonadal steroids modulate adrenal fasciculata 3 beta-hydroxysteroid dehydrogenase-isomerase activity in mice. Biol Reprod. 1992;46(1):73-82.

25. Feltus FA, Cote S, Simard J, Gingras S, Kovacs WJ, Nicholson WE, et al, Glucocorticoids enhance activation of the human type II 3betahydroxysteroid dehydrogenase/Delta5-Delta4 isomerase gene. J Steroid Biochem Mol Biol. 2002;82(1):55-63.

26. Xiao YC, Huang YD, Hardy DO, Li XK, Ge RS. Glucocorticoid suppresses steroidogenesis in rat progenitor Leydig cells. J Androl. 2010;31(4):365-71.

27. Li R, Sun $Q$, Jia $Y$, Cong $R, N i$, Yang $X$, et al. Coordinated miRNA/mRNA expression profiles for understanding breed-specific metabolic characters of liver between Erhualian and large white pigs. PLoS One. 2012;7(6), e38716.

28. Li LA, Xia D, Wei S, Hartung J, Zhao RQ. Characterization of adrenal ACTH signaling pathway and steroidogenic enzymes in Erhualian and Pietrain pigs with different plasma cortisol levels. Steroids. 2008;73(8):806-14

29. Desautes C, Sarrieau A, Caritez JC, Mormede P. Behavior and pituitaryadrenal function in large white and Meishan pigs. Domest Anim Endocrinol. 1999;16(4):193-205.

30. Yang X, Liu R, Albrecht E, Dong X, Maak S, Zhao R. Breed-specific patterns of hepatic gluconeogenesis and glucocorticoid action in pigs. Archiv Fur Tierzucht-Arch Anim Breed. 2012;55(2):152-62.

31. Vandesompele J, De Preter K, Pattyn F, Poppe B, Van Roy N, De Paepe A, et al. Accurate normalization of real-time quantitative RT-PCR data by geometric averaging of multiple internal control genes. Genome Biol. 2002;3(7):RESEARCH0034.

32. Feng $X$, Xiong $Y$, Qian $H$, Lei $M, X u D$, Ren Z. Selection of reference genes for gene expression studies in porcine skeletal muscle using SYBR green qPCR. J Biotechnol. 2010;150(3):288-93.

33. Livak KJ, Schmittgen TD. Analysis of relative gene expression data using real-time quantitative PCR and the 2(-Delta Delta C(T)) Method. Methods (San Diego, Calif). 2001;25(4):402-8.

34. Rudiger JJ, Roth M, Bihl MP, Cornelius BC, Johnson M, Ziesche R, et al. Interaction of C/EBPalpha and the glucocorticoid receptor in vivo and in nontransformed human cells. FASEB J. 2002;16(2):177-84.

35. Jia Y, Li R, Cong R, Yang X, Sun Q, Parvizi N, et al. Maternal low-protein diet affects epigenetic regulation of hepatic mitochondrial DNA transcription in a sex-specific manner in newborn piglets associated with GR binding to its promoter. PLoS One. 2013;8(5), e63855.

36. Alastalo TP, Hellesuo M, Sandqvist A, Hietakangas V, Kallio M, Sistonen L. Formation of nuclear stress granules involves HSF2 and coincides with the nucleolar localization of Hsp70. J Cell Sci. 2003;116(Pt 17):3557-70.

37. Dong Y, Poellinger L, Gustafsson JA, Okret S. Regulation of glucocorticoid receptor expression: evidence for transcriptional and posttranslational mechanisms. Mol Endocrinol. 1988;2(12):1256-64.

38. Ramamoorthy S, Cidlowski JA. Ligand-induced repression of the glucocorticoid receptor gene is mediated by an NCoR1 repression complex formed by long-range chromatin interactions with intragenic glucocorticoid response elements. Mol Cell Biol. 2013;33(9):1711-22.

39. Marelli SP, Terova G, Cozzi MC, Lasagna E, Sarti FM, Cavalchini LG. Gene expression of hepatic glucocorticoid receptor NR3C1 and correlation with plasmatic corticosterone in Italian chickens. Anim Biotechnol. 2010;21(2):140-8.

40. Gyles SL, Burns CJ, Whitehouse BJ, Sugden D, Marsh PJ, Persaud SJ, et al. ERKs regulate cyclic AMP-induced steroid synthesis through transcription of the steroidogenic acute regulatory (StAR) gene. J Biol Chem. 2001;276(37):34888-95.

41. Krongrad A, Wilson CM, Wilson JD, Allman DR, McPhaul MJ. Androgen increases androgen receptor protein while decreasing receptor mRNA in LNCaP cells. Mol Cell Endocrinol. 1991;76(1-3):79-88.

42. Nishio $Y$, Isshiki H, Kishimoto T, Akira S. A nuclear factor for interleukin-6 expression (NF-IL6) and the glucocorticoid receptor synergistically activate transcription of the rat alpha 1-acid glycoprotein gene via direct protein-protein interaction. Mol Cell Biol. 1993;13(3):1854-62.

43. Zha Q, Wang Y, Fan Y, Zhu MY. Dexamethasone-induced up-regulation of the human norepinephrine transporter involves the glucocorticoid receptor and increased binding of C/EBP-beta to the proximal promoter of norepinephrine transporter. J Neurochem. 2011;119(3):654-63.
44. Sun H, Sheveleva E, Xu B, Inoue H, Bowden TG, Chen QM. Corticosteroids induce COX-2 expression in cardiomyocytes: role of glucocorticoid receptor and C/EBP-beta. Am J Physiol Cell Physiol. 2008;295(4):C915-922.

45. Lessard J, Tchernof A. Interaction of the glucocorticoid and androgen receptors in adipogenesis. Chem Biol. 2012;19(9):1079-80.

46. Sun Z, Liu M, Zou H, Li X, Shao G, Zhao R. Vaccination inhibits TLR2 transcription via suppression of GR nuclear translocation and binding to TLR2 promoter in porcine lung infected with Mycoplasma hyopneumoniae. Vet Microbiol. 2013;167(3-4):425-33.

\section{Submit your next manuscript to BioMed Central and take full advantage of:}

- Convenient online submission

- Thorough peer review

- No space constraints or color figure charges

- Immediate publication on acceptance

- Inclusion in PubMed, CAS, Scopus and Google Scholar

- Research which is freely available for redistribution

Submit your manuscript at www.biomedcentral.com/submit 